\title{
Group Loans Repayment Problems of Women Borrowers
}

\author{
Umara Noreen \\ Prof. Dr. M. Iqbal Saif
}

\begin{abstract}
Economic growth and development is a dream without having well focused and effective strategies to eradicate poverty through extending credits to women. The mobilization of funds comes directly from the participant's savings and therefore the use of funds is under group scrutiny. This paper aims to examine the repayment problems of women borrowers of microfinance. A sample of 100 respondents comprising 20 groups were interviewed. The groups utilized self-selection of members so that a strong degree of promise, trust and consent exists among members. Limited amount of loan and procedural hurdles were found to be the two major problems in group loans. The strengthened social ties and trust in groups reduce the repayment problems to a large extent. In addition the study noted that groups that were formed by the borrowers themselves had less repayment problems. Surprisingly, group members belonging to different levels of education and income groups had lesser repayment problems. The present study therefore recommends that microfinance institutions in targeting women should improve and smoothen the loaning procedure, extend higher credit limits to socially heterogeneous groups.
\end{abstract}

Keywords: Social ties, trust, repayment problems, self-selection.

\section{Introduction}

"Grameen style" lending is characterized by loans to small groups of borrowers that are jointly liable for the loans granted to each member of their group. The loans are intended for clients who do not meet the wealth requirements of the formal banking system. Since the clients have little material wealth, no collateral requirement exists. The explosion of group lending programs around the world is a recent phenomenon. While a few group loan institutions were operating in the 1970s, a proliferation of such programs occurred in the 1980s and continues to accelerate in the 1990s. Nearly all of the programs are NGO sponsored credit-first approaches. Many advantages to group lending are cited in the literature. An often cited justification for group lending is that it provides pecuniary returns, especially to women who have no other means of exerting their independence. Group credit gives women self-esteem, mutual trust, empowerment, and other psychic benefits which Pakistani women needs. The only guarantee on the loan is the joint liability. The low level of defaults and successful repayment rates of MFIs are result of innovations like peer group loan methodology, in which members accept joint liability for individual loans, dynamic incentives, regular repayment schedules and collateral substitutes (Morduch, 1999a).

Umara Noreen is an Assistant Professor, Management Science, CIIT Islamabad, umaranoreen@comsats.edu.pk Dr. M. Iqbal Saif is affiliated with the Dept. of Sociology at the Allama Iqbal Open University, drmisaif@gmail.com

Journal of Independent Studies and Research - MSSE

Volume $9 \quad$ Number 1

January $2011 \mid 83$ 
The poorest need very small loans with flexible repayment schedules. They do not like to subject themselves to rigid installment amounts and schedules. They also need flexible deposit facilities. They would like to save any amount whenever they can and withdraw any amount whenever they need. The poorest also have strong preferences for certain types of delivery mechanism. Researchers have found that the poorest prefer individual loans, do not wish to participate in group-based programs, and do not like to attend regular meetings (Fernando, 2004).

\section{Literature Review}

\section{Social Ties}

Sharma \& Zeller (1998) have analyzed the repayment rates of 128 credit groups belonging to three group-based credit programs in Bangladesh: the Association for Social Advancement (ASA), the Bangladesh Rural Advancement Committee (BRAC), and the Rangpur Dinajpur Rural Service (RDRS). They studied group size, size of loans, degree of loan rationing, enterprise mix within groups, demographic characteristics, social ties and status, and occurrence of idiosyncratic shocks. It is concluded that if basic principles of prudential banking are adhered to, repayment rates can be good even in poor and remote communities. The important thing for financial institutions is to tailor services such that it becomes worthwhile for the poor to establish a profitable long-term association. In addition, more freedom to members in the process of group formation is recommended.

Micro-finance programs provide poor people with small loans given to jointly liable selfselected groups. Follow-up loans provide incentives to repay. Abbink, Irlenbusch \& Renner (2006) shows the influence of those features on strategic default. They investigate group size and social ties effects and observe robust high repayment rates. Group lending outperforms individual lending. Self-selected groups show high but less stable contributions.

\section{Level of Trust}

Karlan's (2005) studied the importance of innate trustworthiness, as opposed to trustworthiness driven by the fear of social sanctions.

Alessandera (2007) results indicate first that specific trust between a borrower and other individual group members appears to be relatively more important than trust in society as a whole for group loan repayment. Additionally, Alessandra maintains that group lending is likely to be more successful when a borrower faces a pool of potential borrowing partners that contains a large number of people whom she personally trusts. Moreover, to the extent that borrowers have a choice within this pool, it supports the notion that informational social capital in the process of group self-selection and screening is likely to matter in group lending.

In short, consistent with Karlan (2005) no evidence was found that trusting behavior is at all positively related to greater rates of contribution to group loans. (He actually 
finds that it is negatively related, and interprets the result as possibly due to risk loving behavior.)

Personal trust appears to play a far more important role than simple acquaintanceship. The implication is that group lending may not be successful when people simply know one another well. It is more likely to succeed where people can choose among a large number of trustworthy group members. Results offer little support to Besley and Coate's (1995) hypothesis that the potential for social sanctions is vital to group lending. Trust that others will contribute their share is far more significant in our study. Bohnet \& Frey (1999) finds that an accurate portrayal of cooperative behavior is only revealed when social distance diminishes and subjects interact with an identifiable person.

\section{Self Selection}

Gomez \& Santor (2003) presents evidence in favor of the positive effects of informational and relational social capital on group loan repayment. Ahlin and Townsend's (2007) estimation results support the group self-selection models in the wealthier central region near Bangkok, and the models emphasizing the importance of social sanctions in the poorer, northeastern Thailand. Yet the fact that they find strong social ties within borrowing groups to be negatively correlated with group repayment causes them to challenge the idea that group lending works through its ability to harness all types of existing social capital.

Abbink et al. (2006) carry out a conventional lab experiment in which students in the social sciences at the University of Erfurt participate in a microfinance game. Their results show that social ties within groups induce higher, but less stable, group loan repayment and that the performance of borrowing groups with initially weak social ties may grow with experience together in group loan repayment.

Gine' et al. (2005) find evidence that group lending may actually induce moral hazard (through risk-taking and free-riding) rather than reduce it, though group self-selection counteracts some of these problems.

\section{Social Capital}

Coleman (1988) defines social capital as social structure that facilitates certain actions of actors within the structure. In his definition, Coleman specifically highlights the roles of mutual obligation, expectations and trustworthiness, social norms, social sanctions, and the transmission of information. Empirical work that has tried to isolate the influence of social capital on group loan repayment has faced a number of challenges. First, social capital and its various components are notoriously hard to measure. Moreover, groups often self-select over different components of social capital, thus making it endogenous to actual loan repayment. Articles in this regard by Ahlin \& Townsend (2007) and Karlan (2007) have made important inroads in ameliorating these difficulties and studied the effect of different components of relational social capital on group loan repayment. Results indicate that relational social capital in the form of personal trust 
between individuals and social homogeneity within groups has a positive effect on borrowing group performance.

Besley and Coate (1995) who argue that without the potential for social sanctions, group lending may offer little if any advantage over individual lending. However, given that sanctions are sufficiently strong, group lending in their model is able to curtail the moral hazard associated with loan repayment. Social sanctions, combined with peer monitoring also play a role in studies focusing on peer monitoring as social sanctions are typically assumed to be exogenous (Armenda'riz de Aghion, 1999; Banerjee, Besley \& Guinnane 1994; Stiglitz 1990; and Wydick 2001).

Results demonstrate that borrower self-selection process used in most group lending schemes improves repayment rates through mitigating adverse selection in credit markets (Ghatak , 1999 \& Van Tassel, 1999). The advantages of group lending over individual lending rest on neither the potential for social sanctions nor informational flows between members. Instead, the potential advantage of group lending arises simply from the terms of a joint liability contract.

The best example of this view is Armenda'riz de Aghion and Gollier (2000). They show that, in a pool of safe and risky borrowers, if the higher return realised by a risky borrower in the good state of nature is (uniquely) sufficient to cover for a defaulting group member, and then the group lending contract can reduce the equilibrium interest rate and induce higher repayment rates relative to individual lending. The interesting point about their result is that unlike the models of Van Tassel and Ghatak (1999), it does not rely on borrowers having an informational advantage over the lender. Their model is, however, sensitive to changes in assumptions about borrower returns.

Cull, Demirgu"c-Kunt \& Morduch (2007) explains the importance of other institutional factors to borrower performance such as investments in quality loan officers and other staff. There is probably no single factor that is alone responsible for the frequent success with group lending.

\section{Peer Monitoring}

Karlan (2007) claims to improve repayment rates by providing incentives for peer's to screen, monitor and enforce each other's loans. But some argue that group liability actually discourages good clients from borrowing by creating tension among group members and causing dropouts, jeopardizing growth and sustainability. They find that converting group liability to individual liability, while keeping aspects of group lending like weekly repayments and common meeting place, does not affect the repayment rate, and actually attracts new clients.

In the model of Wydick (2001) it is rational for group members to replace a defaulting member with a new member, even when there is no informational evidence of risky borrower behavior. In a high-information environment, expulsions and replacements are only carried out if there is observable evidence of risky behavior. Wenner (1995) provides some evidence that active screening and social pressure among members of 
25 Costa Rican credit groups improved group performance. Zeller (1998) finds credit group performance positively related to social cohesion within groups. Wydick (1999) finds that while peer monitoring appears to have some positive effect on group loan repayment, strong social ties within groups appear to make it more difficult to pressure fellow members to repay loans.

Based on the discussion in the literature review, present study has taken three important variables that affect loan repayment. These are level of trust/ trust-worthiness, social ties, group self selection. After analysis, following hypotheses are generated: H1- Level of trust among group members reduces the repayment problems. $\mathrm{H} 2-$ Greater social ties among group members help in reducing repayment problems. H3- The greater the extent to which an individual is involved in choosing his/her group members, the less will be the repayment problems.

\section{Methodology}

The First Microfinance Bank, Rawalpindi Branch was selected to determine the problems being faced by women group borrowers in Pakistan. Face to face 100 interviews were conducted to collect primary data. Instrument used by Vigenina \& Kritikos (2004) has been taken as a base line. However some of the items are added from the instrument used by Paxton (1996). Nunnaly (1978) has indicated 0.7 to be an acceptable reliability coefficient but lower thresholds are sometimes used in the literature. This study has the value of Cronbach's alpha as $\mathbf{0 . 7 1 3}$. Some of the items were deleted in order to enhance the reliability after the first pilot study.

1) Times loan is taken,

2) Group formation,

3) Group interaction

4) Change in members and

5) Pressure.

Majority of the customers had taken loan for the first or second time and they had to make the group by themselves. The group includes minimum 5 members.

\section{Results and Discussions}

Sample consisted of $90 \%$ females and $10 \%$ males comprising of 20 groups. Major businesses in which borrowers were involved included sewing business, embroidery business, tailoring business, selling cloth business, sanitary business, and beauty parlor business. As it is evident from the figure 1, $60 \%$ of women had sewing and embroidery businesses, $30 \%$ had tailoring and cloths selling and only $10 \%$ women had beauty parlors. 


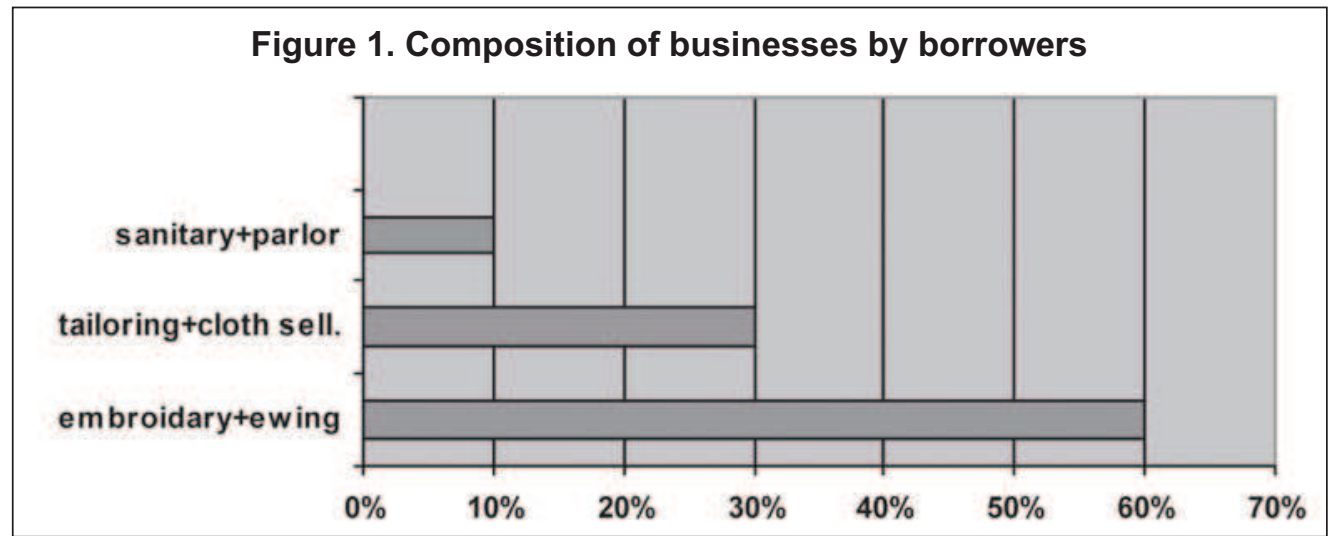

It was revealed that 13 groups have taken loans for more than 1 time, which means that they are satisfied with the bank.

When analyzed the common problems faced by the borrowers it was revealed that common problems that are prevailing in group's loan include the limited loan amount and initial loan taking procedure. FMFB visits borrowers home or the business place to keenly examine his/her business activities. If the bank gets satisfied by the examination then it approves the loan which was then given to the borrower within 20 days. $60 \%$ respondents said that the amount that was given to them by FMFB insufficient to fulfill their business needs (figure 2). $30 \%$ replied that long procedure was the main problem in loaning procedure. The loan amount ranges from Rs 15,000-20,000. The amount that was given to the first time borrowers is not more than merely Rs 15,000 and second or third time borrowers can get Rs 20,000 at maximum.

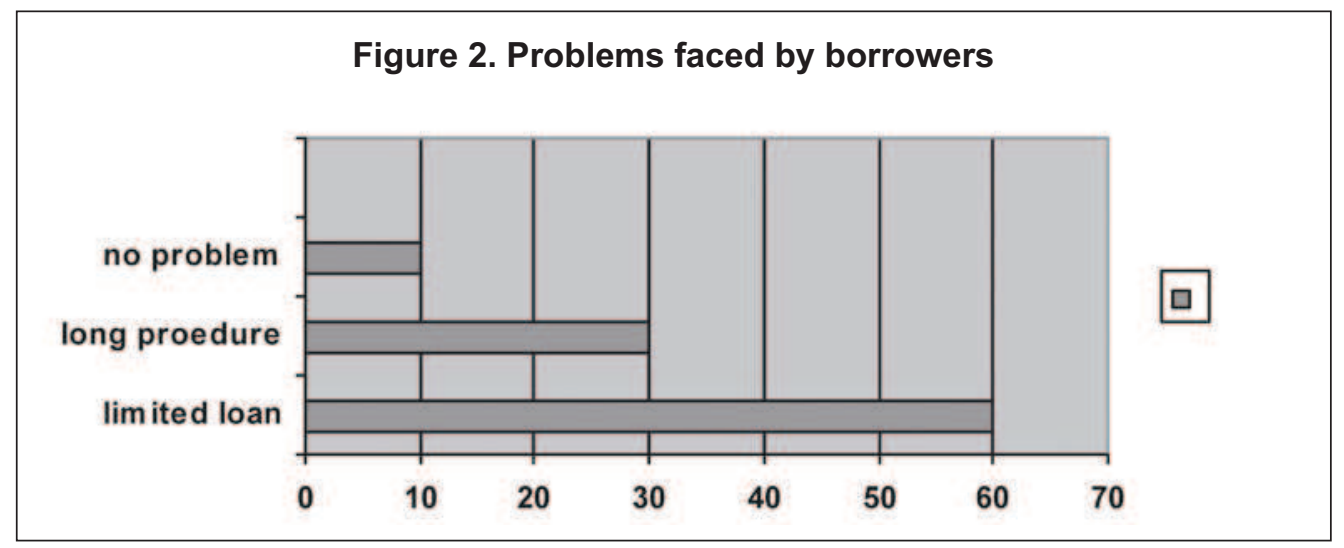


Table 1. Frequencies and Percentages: Summary

\begin{tabular}{|c|c|c|c|c|}
\hline & & Frequency & Percent & Valid Percent \\
\hline Group Meeting & yes & 100 & 100.0 & 100.0 \\
\hline Group Formation & yourself & 100 & 100.0 & 100.0 \\
\hline \multirow{4}{*}{$\begin{array}{l}\text { No of times loan } \\
\text { was taken }\end{array}$} & one time & 56 & 56.0 & 56.0 \\
\hline & 2 times & 25 & 25.0 & 25.0 \\
\hline & 3 times & 18 & 18.0 & 18.0 \\
\hline & more than 3 & 1 & 1.0 & 1.0 \\
\hline \multirow[t]{2}{*}{ Same sex } & yes & 74 & 74.0 & 74.0 \\
\hline & no & 26 & 26.0 & 26.0 \\
\hline \multirow[t]{2}{*}{ Same education } & yes & 8 & 8.0 & 8.0 \\
\hline & no & 92 & 92.0 & 92.0 \\
\hline \multirow{2}{*}{$\begin{array}{l}\text { Same level of } \\
\text { wealth }\end{array}$} & yes & 17 & 17.0 & 17.0 \\
\hline & no & 83 & 83.0 & 83.0 \\
\hline \multirow{3}{*}{$\begin{array}{l}\text { Change of } \\
\text { members in credit } \\
\text { group }\end{array}$} & none & 83 & 83.0 & 83.0 \\
\hline & once & 10 & 10.0 & 10.0 \\
\hline & twice & 7 & 7.0 & 7.0 \\
\hline \multirow[t]{4}{*}{ Difficulty in repaying } & loss in business & 9 & 9.0 & 9.0 \\
\hline & $\begin{array}{l}\text { large family } \\
\text { expense }\end{array}$ & 2 & 2.0 & 2.0 \\
\hline & death in a family & 1 & 1.0 & 1.0 \\
\hline & No problems & 88 & 88.0 & 88.0 \\
\hline \multirow{3}{*}{$\begin{array}{l}\text { Who helped the } \\
\text { member(s) who had } \\
\text { difficulty in repaying }\end{array}$} & family & 5 & 5.0 & 5.0 \\
\hline & husband & 8 & 8.0 & 8.0 \\
\hline & group & 87 & 87.0 & 87.0 \\
\hline \multirow{3}{*}{$\begin{array}{l}\text { Group ever paid for } \\
\text { one of its members }\end{array}$} & yes & 98 & 98.0 & 98.0 \\
\hline & No & 1 & 1.0 & 1.0 \\
\hline & others & 1 & 1.0 & 1.0 \\
\hline \multirow{3}{*}{$\begin{array}{l}\text { credit group exert } \\
\text { pressure on } \\
\text { partners who report } \\
\text { repayment } \\
\text { problems }\end{array}$} & No pressure & 7 & 7.0 & 7.0 \\
\hline & some pressure & 56 & 56.0 & 56.0 \\
\hline & strong pressure & 37 & 37.0 & 37.0 \\
\hline
\end{tabular}

As it is clear from table 1, that group members had $100 \%$ interaction and they meet regularly other than the loan servicing. The groups in FMFB are made by the customers themselves. FMFB do not play any role in the formation of the group. Mostly people prefer to form groups with their neighbors. This shows that people are happy with the group self-selection.

Majority of the respondents took loan for the first time i.e. $56 \%$. There were very few groups who took loan more than 3 times from FMFB. The frequency of respondents who took loan for 2 nd is $25 \%$ and 3 rd time is $18 \%$. It was found that $74 \%$ of the group members were of the same sex (table 1).Further, $92 \%$ of the group members had different level of education. This means that education factor does not play a significant part in group self-selection. People made groups on the basis of their social interaction and social ties with other people in their neighbors. The level of wealth within the group varies. The members have different income range and may not have same financial standing. This also supports the hypothesis that people don't make groups on the basis of wealth, rather they only prefer to made groups on the basis of social ties with their neighbors, because only few groups have same wealth level. 
Majority of the members were happy with their group and hadn't change any of their member. There were 2 groups who changed their member once, only because she was having repayment problem and second one died. Another group had to change their member 2 times because they were having repayment problem. Group members belief each other and they have a strong trust among them that if any single member sometimes fails to make repayment, then others will pay his/her part. And then after some time he/she will return them that amount. This also supports the hypothesis that strong trust reduces repayment problems. And also people are satisfied with self-selected groups, because more than $80 \%$ groups didn't change their groups ever. $88 \%$ of the respondents reported no problem in paying installment on time. Others, $12 \%$ only, who reported repayment problem was mainly because of loss in business, followed by large family expense and death in family.

The members of a group help each other in case any member is having repayment problem. Family and husband also support them but the most of the time it is the group members (according to $87 \%$ of the respondents). This also holds true for our hypothesis that group member trust each others and help out other members in their difficult times.

$98 \%$ of the respondents pay for the member who had difficulty in repayment. Majority of the respondents were helpful when needed. Only $1 \%$ does not pay or help the member having repayment problem. This also supports the hypothesis that trustworthiness binds the group together. Members can easily manage their money and payment issues, as they trust each other.

The frequency distribution shows that $37 \%$ of the respondents exert strong pressure on one another for repayment and $56 \%$ have some pressure on partners. This indicates a positive sign for microfinance institutions who are offering loans only on guarantees of one another. Authors have further extended the analyses by conducting cross tabulations in order to get the indebt insights. Cross tabulation was done to determine the relationship between same level of education of group members and number of times members changed in a credit group.

Figure 3. Same level of education vs. number of times the members changed in a credit group

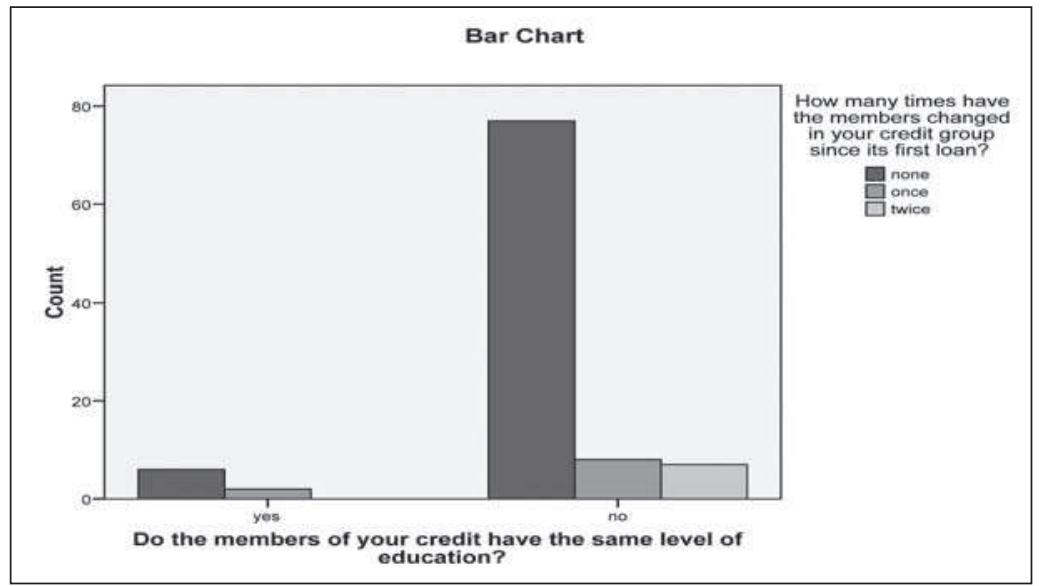


The chart above shows the relationship between the level of education and change in group member because of repayment problem. We have analyzed that same level of education does not mean that people will not have repayment problem. The highest bar chart predicts that member do not change or change less often in a group who do not have same level of education. It shows that the groups with same education level are more vulnerable in changing group members. However the groups with different education levels (who replied no) have bar representing none at $77 \%$. This shows that people with different education levels are more satisfied with their groups than the one with same education.

Figure 4. Same wealth level vs. group paid for one its members.

Bar Chart

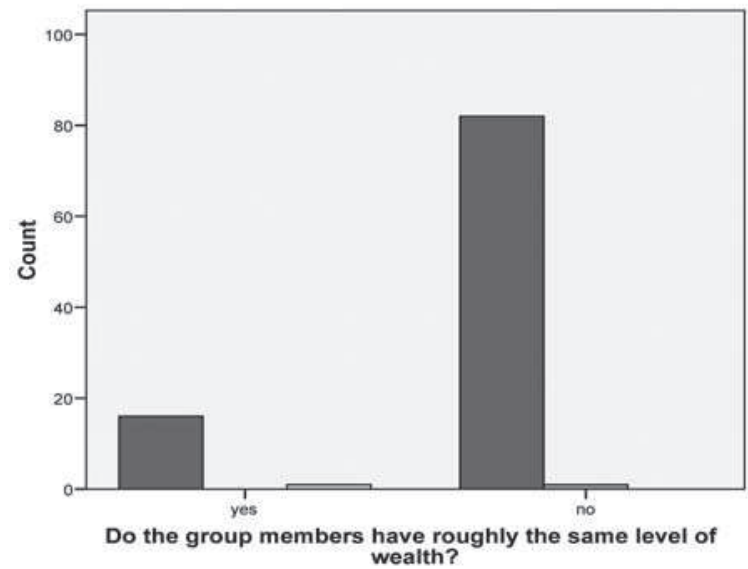

Has the group ever

paid for one of its members who had
difficuty in repaying?

吕 yos

others

This infers that the groups which have same wealth level are not helpful with their members. Only $16 \%$ said that they pay for the other members. But the groups with different wealth levels are more helpful for their members. They pay in place of any other member if he/she is not able to pay. That member will then return that amount to the payee.

Figure 5. Same age vs. reasons for difficulty in repayment.

Bar Chart

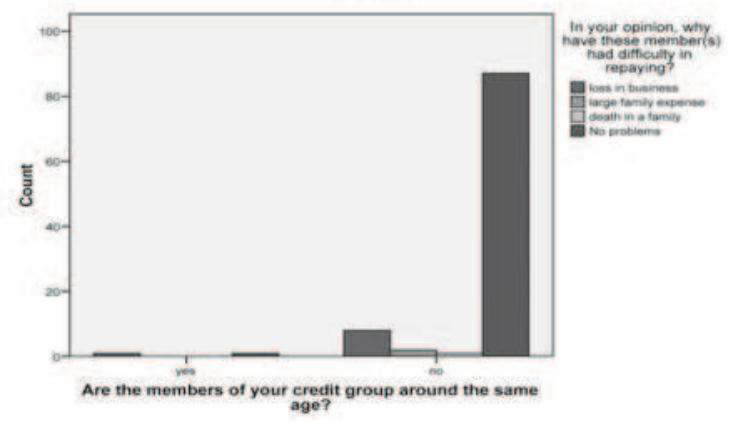


This shows that group having people of different age groups make repayments on time and they don't have any difficulty in repayments.

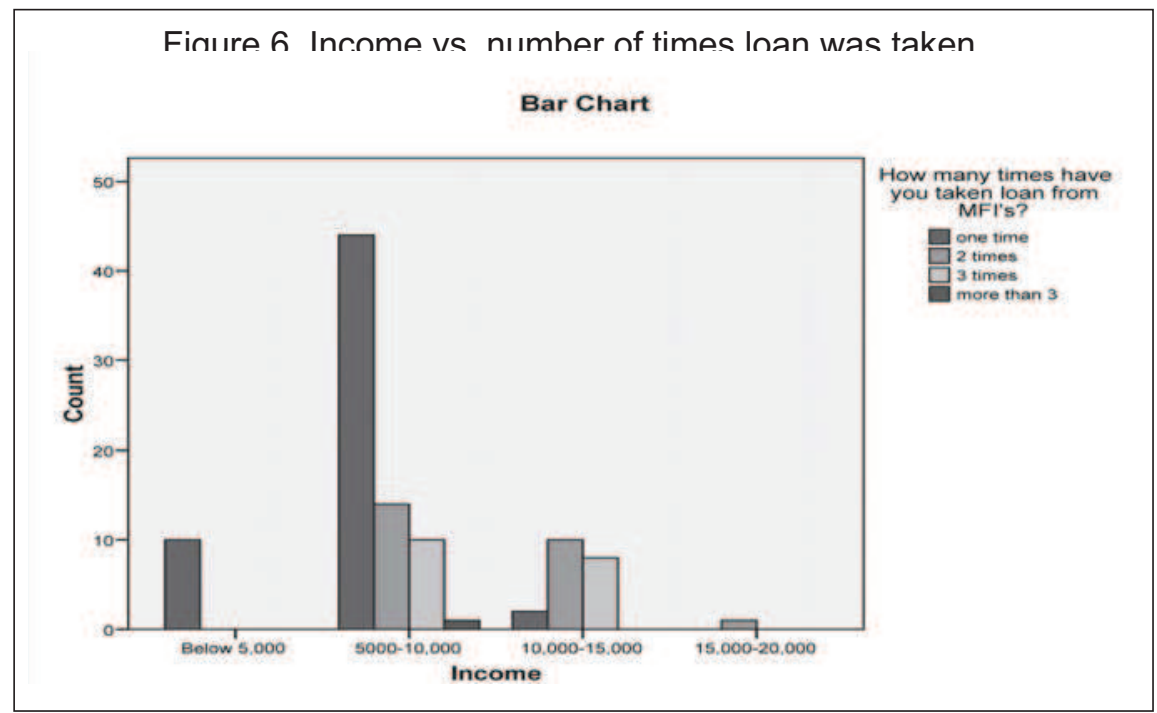

The relationship between income level of groups and the number of times they take micro-loans show that those people whose income ranges from Rs. 5,000-10,000 are more inclined to take these micro-loans. Among the respondents of this income level, 44 people have applied for the 1st time, 14 have applied for the second time, 10 people have applied for the third time and also 1 respondent have applied for the loan more than three times. This depicts that the borrowers who fall within this income range are FMFBs major targeted customers.

Figure 7. Income vs. number of times members changed in credit group

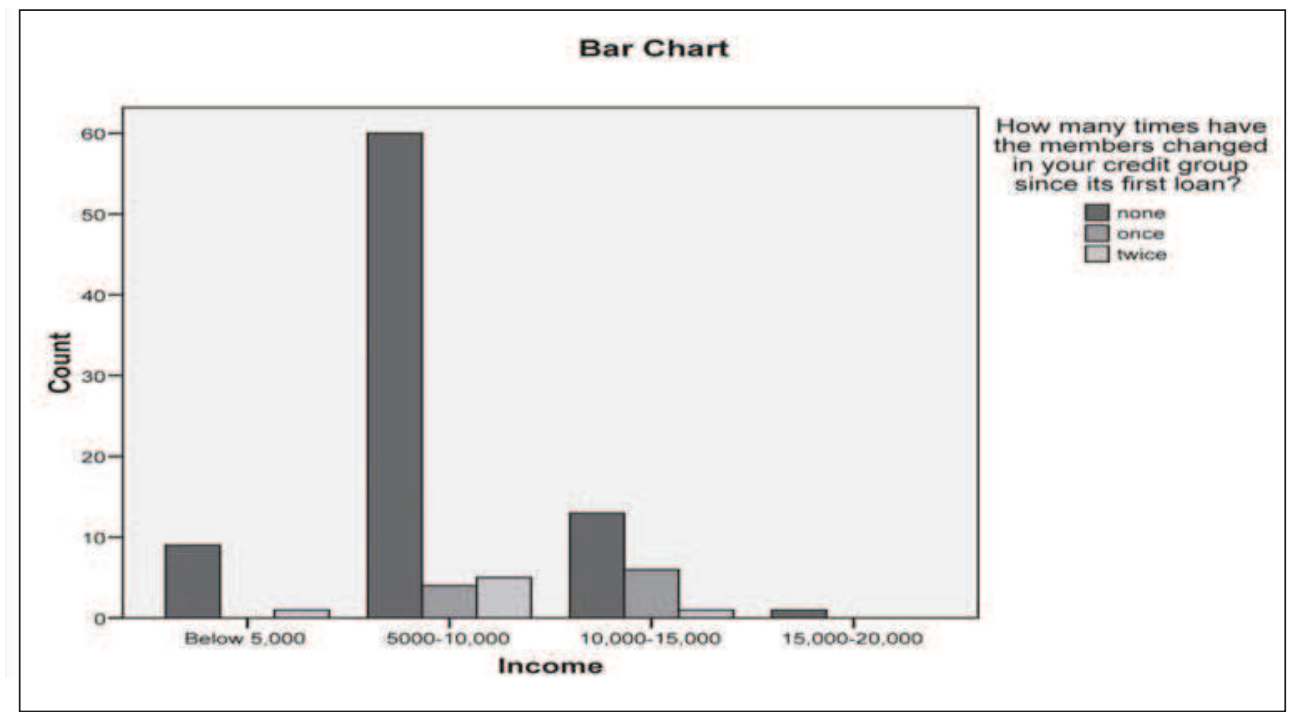


This shows that borrowers who lie in the income range of Rs.10,000-15,000 are more vulnerable to change their group members as compare to others. Here $11 \%$ members have changed the group in income level below Rs. 5,000,15\% members have changed the group having income level Rs. 5,000-10,000 and 54\% members have changed the group having income level of Rs. 10,000-15,000. This shows that borrowers having income less than Rs. 10,000 are more satisfied with their group members and they rarely change their members.

\section{Conclusion}

The notion of microfinance revolves around group lending and joint liability. The level of trust-worthiness among group members, their social ties, formation of groups etc play major part in applying for microfinance loan. Previous studies have shown that countries such as Afghanistan, Myanmar and Pakistan have low outreach due to a variety of factors. Despite these disparity within the region, overall it is said that MFIs have flourished in Asia and, that compared to other regions, they exhibit good outreach and high repayment rates (Zeller \& Meyer 2002). Present study has also shown the similar results and has drawn important implications for micro financial institutions in general and FMFB in particular. Two major problems which the clients are facing are limited amount of loan and long procedure. Group formation is carried out the by the members themselves and usually they live in neighborhoods. Most of them meet one another often other than the loan servicing exhibiting the strong social ties among themselves and do not have any repayment problems. It was revealed that socially heterogeneous groups consistently perform better as compared to socially homogeneous groups supports the notion that relational social capital matters to group lending. Groups comprising of different age groups, education and income level perform even better.

To conclude all this, it can be generalized that more the group members trust each other the less are their repayment problems. The more the social ties among group the less are the repayment problems. The more the groups are based on self-election more satisfied the group members and lesser the repayment problems.

\section{Limitations of the Study}

Like any other study, this study is not without limitations. Present study was restricted to only a single microfinance bank. The sample size can be extended and interviews can be conducted from other micro financial institutions. The instrument used new items on social capital and social ties can be explored and added by conducting focus groups. 


\section{References}

Abbink, K., Irlenbusch, B. and Renner, E. (2006), Group size and social ties in microfinance institutions, Economic Inquiry, vol. 44 (4), pp. 614-28.

Ahlin, C. and Townsend, R. (2007), Using repayment data to test across models of joint liability lending, Economic Journal, vol. 117, pp. F11-F51.

Armenda'riz de Aghion, B. (1999), On the design of a credit agreement with peer monitoring, Journal of Development Economics, vol. 60(1), pp. 79-104.

Armenda'riz de Aghion, B. and Gollier, C. (2000), Peer group formation in an adverse selection model, Economic Journal, vol. 110, pp. 632-43.

Armenda'riz de Aghion, B. and Morduch, J. (2005), The Economics of Microfinance, Cambridge MA: MIT Press.

Banerjee, A., Besley, T. and Guinnane, T. (1994). Thy neighbor's keeper: design of a credit cooperative with theory and a test, Quarterly Journal of Economics, vol. 102(9), pp. 491-515.

Beatriz Armendáriz de Aghion and Jonathan Morduch, (2000), Microfinance beyond group lending, Economics of Transition Volume 8 (2) , pp.401-420.

Besley, T. and Coate, S. (1995). Group lending, repayment incentives and social collateral, Journal of Development Economics, vol. 46(1), pp. 1-18.

Bohnet, I. and Frey, B. (1999). Social distance and other-regarding behavior in dictator games: comment, American Economic Review, vol. 89(1), pp. 335-9.

Cassar, A., Crowley, L., \& Wydick, B. (2007), The effect of social capital on group loan repayment: evidence from field experiments, Economic Journal, Vol. 117, No. 517, pp. 85-106.

Casser, Crowley and Wydick (2007), The effect of social capital on group loan Repayment: evidence from field experiments, The Economic Journal, 117 (February), F85-F106.

Coleman, J. (1988), Social capital in the creation of human capital, American Journal of Sociology, vol. 94, pp. 95-120.

Cull, R., Demirgu"c-Kunt, A. and Morduch, J. (2007), Financial performance and outreach: a global analysis of leading micro banks, Economic Journal, vol. 117, pp. F107-F133.

Fernando, N. A. (2004), Microfinance Outreach to the Poorest: A realistic Objective? Focal Point for Microfinance, Vol:5, No:1, p.1-5.

Ghatak, M. (1999), Group lending, local information and peer selection, Journal of 
Development Economics, vol. 60(1), pp. 27-50.

Ghatak, Maitreesh (2000), 'Joint Liability Credit Contracts and the Peer Selection Effect', Economic Journal, forthcoming, July.

Ghatak, Maitreesh and Timothy Guinnane (1999), 'The Economics of Lending with Joint Liability: Theory and Practice', Journal of Development Economics, 60, pp. 195-228.

Gine', X., Jakiela, P, Karlan, D. and Morduch, J. (2005), Microfinance games, Working Paper, Yale University and New York University.

Glaeser, E, Laibson, D, Scheinkman, J. and Soutter, C (2000), Measuring trust, Quarterly Journal of Economics, vol. 115, pp. 811-46.

Gomez, R. and Santor, E. (2003), Do peer group members outperform individual borrowers? A test of peer group lending using Canadian micro credit data, Bank of Canada, Working Paper (October).

Harrison, G. and List, J. (2004), Field experiments, Journal of Economic Literature, vol. 62 , pp. 1009-55.

Karlan, D. (2005), Using experimental economics to measure social capital and predict financial decisions, American Economic Review, vol. 95, pp. 1688-99.

Karlan, D. (2007), Social connections and group banking, Economic Journal, vol. 117, pp. F52-F84.

Khandker, S.R., Khalily, B, and Khan, Z. (1996), Credit programs for the poor: Household and intrahousehold impacts and program sustainability. Dhaka, Bangladesh: Bangladesh Institute of Development Studies. Volume I.

Kritikos, S. A., \& Vigenina (2004). Key factors of joint-liability loan contracts an empirical analysis, Dept. of Economics, Europe-University Viadrina, Frankfurt.

Laffont, Jean Jacques (2000), 'Collusion and Group Lending with Adverse Selection', IDEI, Toulouse, draft, January.

Laffont, Jean Jacques and T. T. N'Guessan (1999), 'Group Lending with Adverse Selection', European Economic Review, forthcoming.

Montgomery, R. (1996), Disciplining or protecting the poor? Avoiding the social costs of peer press in micro-credit schemes. Journal of International Development, Vol. 8, No. 2.

Morduch, J. (1999a), The microfinance promise. Journal of Economic Literature, Vol:37, No:, p. 569-614.

Nunnally, J. (1978), Psychometric Theory (2nd ed). New York: McGraw-Hill. 
Paxton, A, J., (1996), Determinants of successful group loan repayment: An application to Burkina Faso dissertation Presented in Partial Fulfillment of the Requirements for the Degree Doctor of Philosophy in the Graduate School of The Ohio State University.

Paxton, M.L.S., M.A. (1996), Determinants of Successful Group Loan Repayment: An Application to Burkina Faso, the Ohio State University.

Scott, J. (1976), The Moral Economy of the Peasant, New Haven: Yale University Press.

Stiglitz, J. (1990), Peer monitoring and credit markets, The World Bank Economic Review, vol. 4(3), pp. 351-66.

Van Tassel, E. (1999), Group lending under asymmetric information, Journal of Development Economics,vol. 60(1), pp. 3-25.

Wenner, M. (1995), Group credit: a means to improve information transfer and loan repayment performance Journal of Development Studies, vol. 32(1), pp. 263-81.

Wydick, B. (1999), Can social cohesion be harnessed to mitigate market failures? Evidence from group lending in Guatemala, Economic Journal, vol. 109, pp. 463-75.

Wydick, B. (2001), Group lending under dynamic incentives as a borrower discipline device, Review of Development Economics, vol. 5(3), pp. 406-20.

Zeller, M. (1998), Determinants of repayment performance in credit groups: the role of program design,intragroup risk pooling, and social cohesion, Economic Development and Cultural Change, vol. 46(3),pp. 599-620.

Zeller, M., \& Meyer, R. L. (Eds) (2002), The triangle of microfinance: Financial sustainability, outreach and impact, International Food Policy Research institute, Baltimore. London: The Johns Hopkins University Press. 